\title{
Article \\ Modification of Silica Xerogels with Polydopamine for Lipase B from Candida antarctica Immobilization
}

\author{
Honghai Wang ${ }^{1,2}$, Wenda Yue ${ }^{1,2}$, Shuling Zhang ${ }^{1,2}$, Yu Zhang ${ }^{1,2}$, Chunli Li ${ }^{1,2}$ and Weiyi Su ${ }^{1,2, *}$ \\ 1 School of Chemical Engineering and Technology, Hebei University of Technology, Tianjin 300130, China; \\ ctstwhh@hebut.edu.cn (H.W.); ctstyuewenda@163.com (W.Y.); zsl_hhsy@163.com (S.Z.); \\ zyu1327@163.com (Y.Z.); lichunli_hebut@126.com (C.L.) \\ 2 The National and Local Joint Engineering Laboratory for Energy Conservation of Chemical Process \\ Integration and Resources Utilization, Tianjin 300130, China \\ * Correspondence: suweiyi@hebut.edu.cn; Tel.: +86-022-185-0225-9209; Fax: +86-022-6020-2248
}

check for

updates

Citation: Wang, H.; Yue, W.; Zhang, S.; Zhang, Y.; Li, C.; Su, W.

Modification of Silica Xerogels with Polydopamine for Lipase B from Candida antarctica Immobilization. Catalysts 2021, 11, 1463. https:// doi.org/10.3390/catal11121463

Academic Editors: Elisabeth

Egholm Jacobsen, Simona M. Coman and Madalina Tudorache

Received: 5 November 2021

Accepted: 27 November 2021

Published: 30 November 2021

Publisher's Note: MDPI stays neutral with regard to jurisdictional claims in published maps and institutional affiliations.

Copyright: (c) 2021 by the authors. Licensee MDPI, Basel, Switzerland. This article is an open access article distributed under the terms and conditions of the Creative Commons Attribution (CC BY) license (https:// creativecommons.org/licenses/by/ $4.0 /)$.

\begin{abstract}
Silica xerogels have been proposed as a potential support to immobilize enzymes. Improving xerogels' interactions with such enzymes and their mechanical strengths is critical to their practical applications. Herein, based on the mussel-inspired chemistry, we demonstrated a simple and highly effective strategy for stabilizing enzymes embedded inside silica xerogels by a polydopamine (PDA) coating through in-situ polymerization. The modified silica xerogels were characterized by scanning and transmission electron microscopy, Fourier tranform infrared spectroscopy, X-ray diffraction, X-ray photoelectron spectroscopy and pore structure analyses. When the PDA-modified silica xerogels were used to immobilize enzymes of Candida antarctica lipase B (CALB), they exhibited a high loading ability of $45.6 \mathrm{mg} / \mathrm{g}_{\text {support}}$, which was higher than that of immobilized CALB in silica xerogels $\left(28.5 \mathrm{mg} / \mathrm{g}_{\text {support }}\right)$. The immobilized CALB of the PDA-modified silica xerogels retained $71.4 \%$ of their initial activities after 90 days of storage, whereas the free CALB retained only $30.2 \%$. Moreover, compared with the immobilization of enzymes in silica xerogels, the mechanical properties, thermal stability and reusability of enzymes immobilized in PDA-modified silica xerogels were also improved significantly. These advantages indicate that the new hybrid material can be used as a low-cost and effective immobilized-enzyme support.
\end{abstract}

Keywords: Candida antarctica lipase B; silica xerogel; enzyme immobilization; polydopamine; modification

\section{Introduction}

Biocatalysts play a vital role in various scientific fields due to their unique advantages, such as high substrate specificity, outstanding catalytic ability and mild reaction conditions. Biocatalysis, applied in ester synthesis, is useful and its synthetic products can be identical to natural products. Recently, a transesterification reaction catalyzed by lipase (triacylglycerol ester hydrolase, EC 3.1.1.3) has been performed to produce esters [1]. Lipase-catalyzed reactions have been applied to the synthesis of chiral drugs [2], wax esters [3], structural lipids [4] and biodiesel [5]. However, the main bottlenecks of enzyme application are its low thermal stability, poor operational stability and the difficulty of reusing enzymes. Therefore, significant effort has been devoted to exploiting immobilization strategies to stabilize enzymes and endow them with greater stability and reusability [6,7].

In immobilizing enzymes, it is necessary to select an appropriate support material, which can improve the properties of enzymes. Lipases are widely recognized to have a hydrophobic domain [8]. The hydrophobic immobilization of a lipase can act upon its domains, to increase its activity and stability, by interfacial activation $[9,10]$. Thus, materials comprised with ordered mesoporous organosilica, in which organic hydrophobic groups are homogeneously distributed within their frameworks, may be ideal supports for lipase immobilization. Silica xerogel, thanks to a high specific surface area, good mechanical strength, inertness and stability at high temperature, has attracted much attention in 
enzyme immobilization [11,12]. The xerogel synthesis of entrapped enzymes based on silicon-containing compounds has been widely used [13]. The formation principle of a silicon sol-gel matrix for enzyme immobilization consists in the transition of a silicon alkoxide sol into a gel as a consequence of hydrolysis and polycondensation reactions, with the subsequent transformation into a monolithic xerogel, powder or film coating [14]. This method retains the inherent structures biocomposites, showing enzymatic activity and an expanded range of conditions for catalysis [15]. Enzymes' inclusion in xerogel structures allows increasing the resistances thereof to different physical and chemical factors, such as temperature, $\mathrm{pH}$, radiation and aggressive compounds. In general, xerogel-encapsulated enzyme technology is a method for preparing bioactive nanocomposites [16].

However, the limitation of xerogels' entrapping of enzymes is the shrinkage of their structures, which is not conducive to entrapping enzyme due to the large capillary force caused by continuous internal shrinkage [17]. In our previous work, we proposed a strategy of producing an immobilized enzyme-containing xerogel coating on metal packings for reactive distillation, but there was still a relatively weak interaction between the enzyme and the surface of the support, which often lead to the leakage of the enzyme from the support [18]. In addition, mesoporous silica shows a certain brittleness [19]. When a xerogel is subjected to an external force, the partial or complete rupture of its skeletal structure will also lead to the loss and leakage of an entrapped enzyme. Many studies have been conducted to improve the interactions between enzymes and supports, or the mechanical properties of the support. To date, polyacrylamide [20] and glutaraldehyde [21] have been used as crosslinking agents to increase enzyme loading, while glycerol has been used to prevent xerogel cracking [22]. In fact, a simple and effective method of the two problems latter is to coat an active protective layer on the surfaces of pre-xerogel polymers. Inspired by mussel adhesion proteins, polydopamine (PDA) technology has attracted extensive research $[23,24]$. Dopamine molecules have been shown to self-polymerize under alkaline conditions, leading to a facile deposition of PDA coating on a material's surface [25]. More importantly, the residual quinone on the surface of polydopamine or an intermediate displays a nucleophilic amino reaction that can be covalently connected with nucleophilic biological molecules, producing a polydopamine coating that is robust and durable [26]. This provides a new way of improving the interactions between enzymes and supports, and of enhancing the mechanical properties of xerogels. However, to the best of our knowledge, there are few reports on dopamine self-polymerization deposition on the surfaces of xerogel supports aimed at improving the mechanical properties of and interactions between enzymes and supports.

Surface modification with polydopamine has already become an efficient and feasible method of endowing inorganic materials with biological functionality since Messersmith et al. pioneered the single-step formation of polymer film-based dopamine on various substrates [27]. Meanwhile, this method is not involved in complex linkers and is free of organic solvents, making it suitable for biomaterial applications. Furthermore, the abundant functional groups (i.e., catechol and amine) existing on such modified surfaces could enhance enzymes' binding abilities [28]. Therefore, in the present work and based on this idea, we design a new hybrid support by modifying, with polydopamine, the surfaces of silica xerogels. Specifically, CALB was chosen as a model enzyme. Firstly, CALB was encapsulated in silica xerogels by the sol-gel method, denoted as $\mathrm{SiO}_{2}-\mathrm{CH}_{3}-\mathrm{CALB}$. Second, in order to prevent enzyme leakage and improve enzyme stability, the polymer networks in xerogels were coated with polydopamine (denoted as $\mathrm{SiO}_{2}-\mathrm{CH}_{3}-\mathrm{CALB} @ P D A$ ). Finally, the xerogels' mechanical properties and the enzyme-immobilizing ability of $\mathrm{SiO}_{2}$ $\mathrm{CH}_{3}-\mathrm{CALB}$ and $\mathrm{SiO}_{2}-\mathrm{CH}_{3}-\mathrm{CALB} @ \mathrm{PDA}$ were investigated in detail. The results show that $\mathrm{SiO}_{2}-\mathrm{CH}_{3}-\mathrm{CALB} @ \mathrm{PDA}$ had a significant CALB-embedding ability. Compared with the $\mathrm{SiO}_{2}-\mathrm{CH}_{3}-\mathrm{CALB}$, the results showed that PDA-modified $\mathrm{SiO}_{2}-\mathrm{CH}_{3}-\mathrm{CALB}$ had better mechanical properties, thermal stability, storage stability and reusability. This indicated that the new hybrid silica xerogel could be used as a low-cost and relatively effective immobilized-enzyme support. 


\section{Results and Discussion}

\subsection{Characterization}

Figure 1a shows a FTIR spectral comparison of $\mathrm{SiO}_{2}-\mathrm{CH}_{3}-\mathrm{CALB}$ and $\mathrm{SiO}_{2}-\mathrm{CH}_{3}-$ CALB@PDA. The adsorption peaks at $777 \mathrm{~cm}^{-1}$ and $445 \mathrm{~cm}^{-1}$ corresponded to the $\mathrm{Si}-\mathrm{O}-\mathrm{Si}$ group [29]. The band at $1277 \mathrm{~cm}^{-1}$ was assigned to the characteristic peak of $\mathrm{Si}-\mathrm{CH}_{3}$, which proved that MTMS successfully deposited a methyl polymer layer on the silica surface. Other bands, at $3388 \mathrm{~cm}^{-1}$ and $1643 \mathrm{~cm}^{-1}$, belonged to the stretching and bending vibrations of $-\mathrm{OH}$ [30]. After modification by polydopamine, the vibration absorption peak at $3388 \mathrm{~cm}^{-1}$ was significantly enhanced and widened, which was related to the catechol composition of polydopamine [31]. In addition, $\mathrm{SiO}_{2}-\mathrm{CH}_{3}-\mathrm{CALB} @ P D A$ showed a peak at $1508 \mathrm{~cm}^{-1}$, which was ascribed to the bending vibrations of indolequinone groups [32]. The XRD patterns of $\mathrm{SiO}_{2}-\mathrm{CH}_{3}-\mathrm{CALB}$ and $\mathrm{SiO}_{2}-\mathrm{CH}_{3}-\mathrm{CALB} @ P D A$ are illustrated in Figure 1b. There was a relatively wide peak at $2 \theta=22^{\circ}$, which is characteristic of amorphous silica [33]. The peak at $2 \theta<10^{\circ}$ was due to the siloxane network and the xerogel's structure, composed of ordered organic layers [34]. After modification by polydopamine, the intensity of the characteristic peak at $10^{\circ}$ became weak, implying the microstructure of $\mathrm{SiO}_{2}-\mathrm{CH}_{3}-\mathrm{CALB}$ had changed due to the uniformly distributed deposition of polydopamine within the structure of the xerogel [35]. These results indicate that a polydopamine coating formed on the silica xerogel through self-polymerization.

a

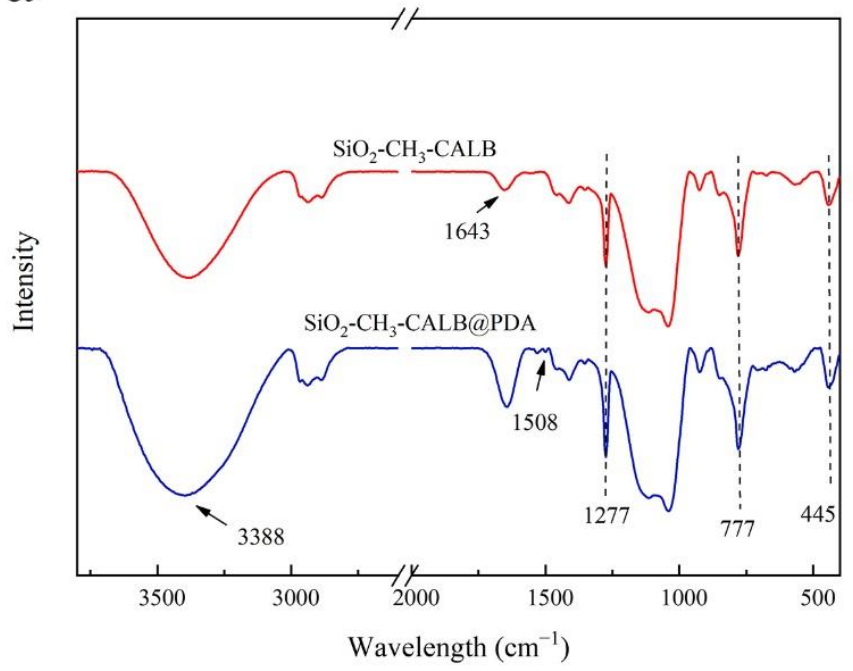

b

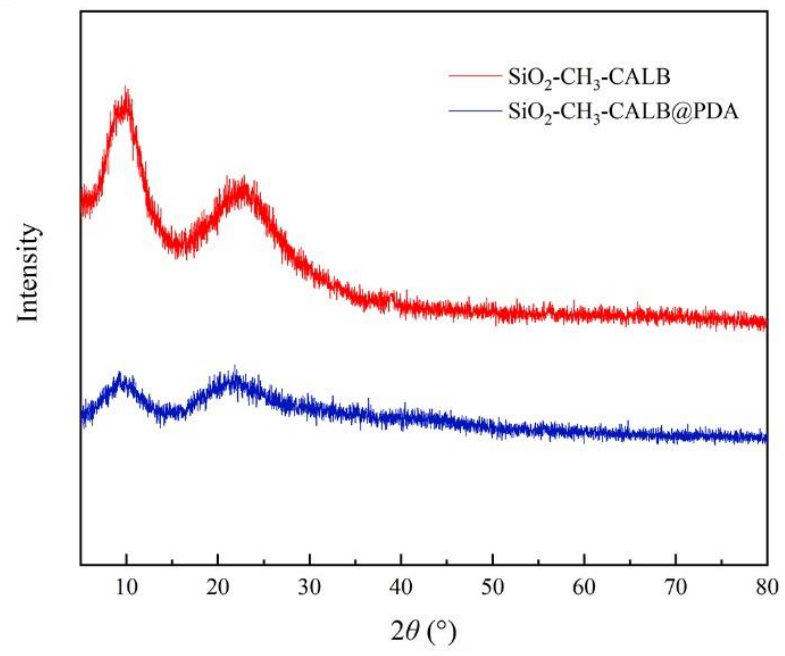

Figure 1. Physical properties of $\mathrm{SiO}_{2}-\mathrm{CH}_{3}-\mathrm{CALB}$ and $\mathrm{SiO}_{2}-\mathrm{CH}_{3}-\mathrm{CALB} @ P D A$. (a) FTIR spectra and (b) XRD $2 \theta$ scans.

Microstructural images of $\mathrm{SiO}_{2}-\mathrm{CH}_{3}-\mathrm{CALB} @ \mathrm{PDA}$ are shown in Figure 2. Figure 2a,b shows the SEM images of the $\mathrm{SiO}_{2}-\mathrm{CH}_{3}-\mathrm{CALB}$ and $\mathrm{SiO}_{2}-\mathrm{CH}_{3}-\mathrm{CALB} @ P D A$ prepared in this work, respectively by panel. They were constituted by the agglomeration of many silica clusters in uniform shape. Compared with $\mathrm{SiO}_{2}-\mathrm{CH}_{3}-\mathrm{CALB}$, the surface of $\mathrm{SiO}_{2}-\mathrm{CH}_{3}-$ CALB@PDA was rougher and looser between clusters, indicating that a polydopamine layer had formed on the $\mathrm{Si}-\mathrm{O}-\mathrm{Si}$ surface. In this structure, the formation of a protective enzyme barrier can absorb and disperse most of the energy from external forces, preventing the xerogel from breaking [36]. TEM images of monodispersed $\mathrm{SiO}_{2}-\mathrm{CH}_{3}-\mathrm{CALB} @ P D A$ showed that its particles have a relatively uniform, nano-scale size (Figure 2c); a more intuitive expression is shown in Figure 2d. The shape of the $\mathrm{SiO}_{2}-\mathrm{CH}_{3}-\mathrm{CALB} @ P D A$ particles irregularly spherical. Additionally, the $\mathrm{SiO}_{2}-\mathrm{CH}_{3}-\mathrm{CALB} @ P D A$ surface had openframework channels (Figure 2e) that facilitated the diffusion of the substrate and product molecules [37]. Elemental mapping analysis (Figure $2 g-j$ ) demonstrated that PDA was uniformly distributed within the xerogel (as these contained nitrogen), and oxygen, carbon 
and silicon were also found in the $\mathrm{SiO}_{2}-\mathrm{CH}_{3}-\mathrm{CALB} @$ PDA surface. Notably, the oxygen content was high.
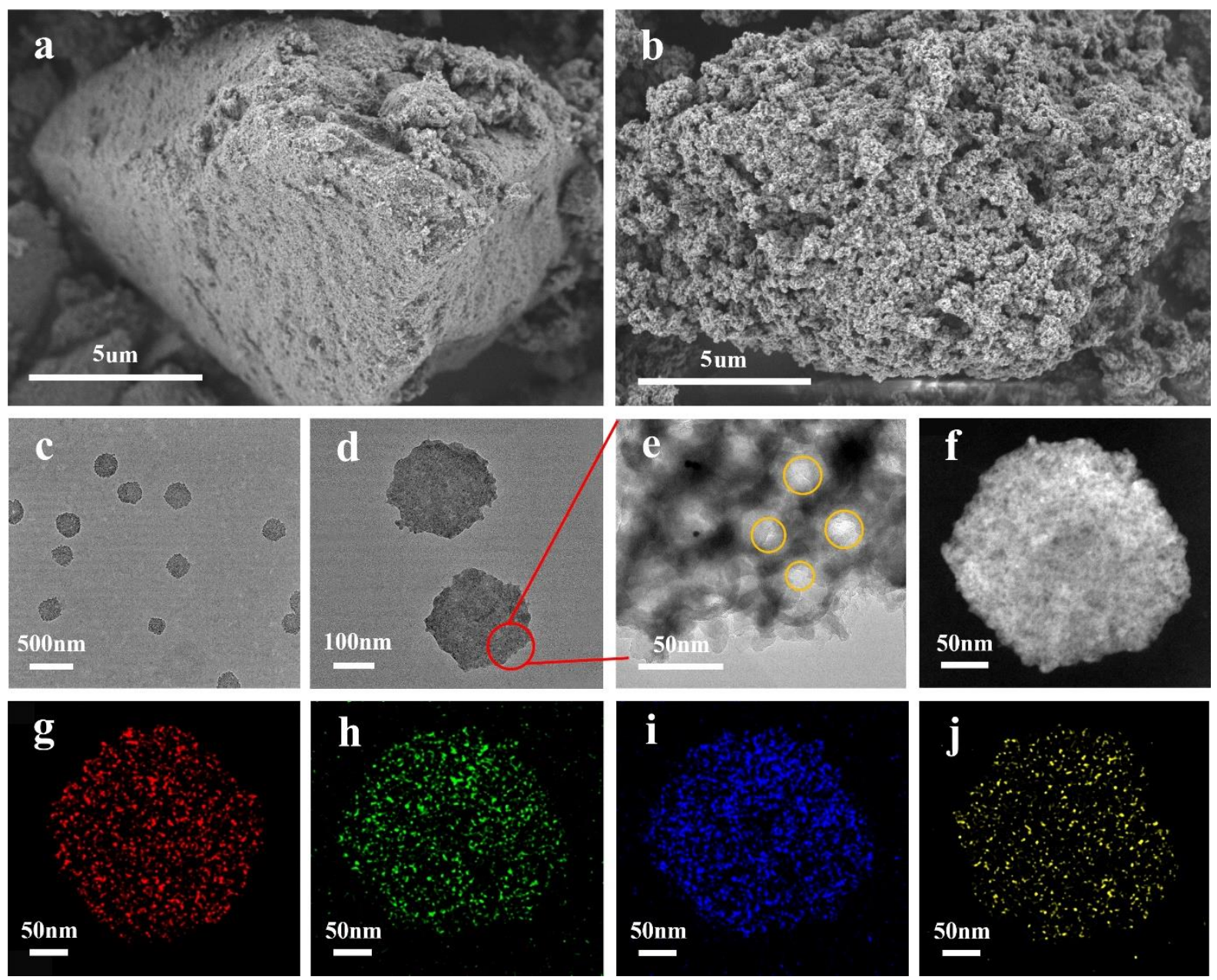

Figure 2. SEM images of (a) $\mathrm{SiO}_{2}-\mathrm{CH}_{3}-\mathrm{CALB}$, (b) $\mathrm{SiO}_{2}-\mathrm{CH}_{3}-\mathrm{CALB} @ P D A,(\mathbf{c}-\mathbf{e})$ TEM images of $\mathrm{SiO}_{2}-\mathrm{CH}_{3}-\mathrm{CALB} @ \mathrm{PDA}$ and $(\mathbf{f}-\mathbf{j})$ elemental mapping analysis of $\mathrm{SiO}_{2}-\mathrm{CH}_{3}-\mathrm{CALB} @ P D A(T E M)$.

XPS measurements in Figure 3 confirmed the existence of polydopamine coating on $\mathrm{SiO}_{2}-\mathrm{CH}_{3}-\mathrm{CALB} @ P D A$. XPS spectra of $\mathrm{SiO}_{2}-\mathrm{CH}_{3}-\mathrm{CALB} @ P D A$ show the presence of $\mathrm{C}$, $\mathrm{N}, \mathrm{O}$ and $\mathrm{Si}$ (Figure $3 \mathrm{a}$ ). The different chemical states of $\mathrm{C}, \mathrm{O}$ and $\mathrm{N}$ in the regional spectra reveal the complex properties of polydopamine on $\mathrm{SiO}_{2}-\mathrm{CH}_{3}-\mathrm{CALB} @ P D A$ (Figure $3 \mathrm{~b}-\mathrm{d}$ ). The main peaks of $C 1$ s spectra (Figure $3 b$ ) at 283.9, 284.5, 285.7, 286.4 and $287.2 \mathrm{eV}$, respectively, corresponding to $\mathrm{C}-\mathrm{C}, \mathrm{C}-\mathrm{N}, \mathrm{C}-\mathrm{O}, \mathrm{C}=\mathrm{O}$ bands, $\mathrm{O}-\mathrm{C}=\mathrm{O}$ and feature for aromatic carbon species in the polydopamine. In the O1s peak (Figure 3c), two peaks were observed at $531.9 \mathrm{eV}$ and $532.7 \mathrm{eV}$, respectively, which belonged to $\mathrm{O}$ atoms of polydopamine in the form of quinone and catechol [38]. The high-resolution spectra of $\mathrm{N}$ 1's peak are shown in Figure 3d. The main peak, at $399.4 \mathrm{eV}$, indicated the existence of $\mathrm{R}_{2} \mathrm{NH}$ and $\mathrm{RNH}_{2}$, while the peak at $401.2 \mathrm{eV}$ was attributed to $\mathrm{R}_{3} \mathrm{~N}$ [39]. This result indicates that an adhesive polydopamine coating formed on the surface of the $\mathrm{Si}-\mathrm{O}-\mathrm{Si}$ network structure of the xerogel by self-polymerization.

Figure $4 \mathrm{a}-\mathrm{c}$ and Figure $4 \mathrm{~d}-\mathrm{f}$ show the sol-gel process and finished products, $\mathrm{SiO}_{2}-$ $\mathrm{CH}_{3}-\mathrm{CALB}$ and $\mathrm{SiO}_{2}-\mathrm{CH}_{3}-\mathrm{CALB} @ \mathrm{PDA}$, respectively. They were no significant differences in the solution phase (sol), showing a slightly yellow liquid (Figure $4 \mathrm{a}$,d). Then, they entered the gel phase, the $\mathrm{SiO}_{2}-\mathrm{CH}_{3}-\mathrm{CALB}$ showed a milky white gel block, while the $\mathrm{SiO}_{2}-\mathrm{CH}_{3}-\mathrm{CALB} @ P D A$ showed a black transparent gel block (Figure $4 \mathrm{~b}, \mathrm{e}$ ). This may be explained by dopamine's having begun to self-polymerize into polydopamine on the 
gel network. After the final drying stage, The final samples of $\mathrm{SiO}_{2}-\mathrm{CH}_{3}-\mathrm{CALB}$ and $\mathrm{SiO}_{2}-\mathrm{CH}_{3}-\mathrm{CALB} @ \mathrm{PDA}$ were obtained by grinding (Figure $\left.4 \mathrm{c}, \mathrm{f}\right)$.
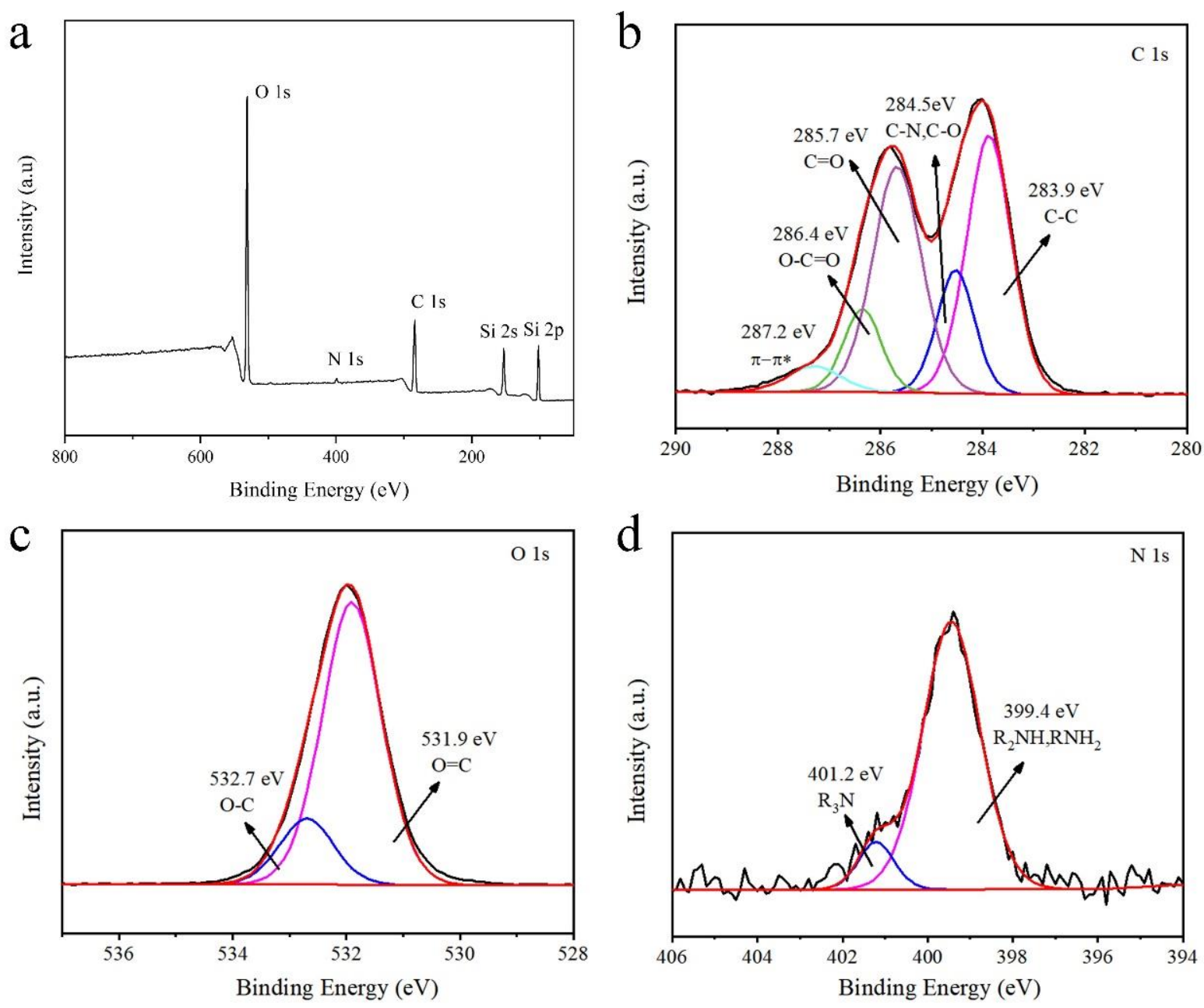

Figure 3. XPS analyses of $\mathrm{SiO}_{2}-\mathrm{CH}_{3}-\mathrm{CALB} @ P D A$. (a) Survey scan, (b) $\mathrm{C} 1 \mathrm{~s}$, (c) $\mathrm{O}$ 1s and (d) N 1s.

With the aim of further prove the PDA can delay shrinkage of xerogel, analysis of BET of $\mathrm{SiO}_{2}-\mathrm{CH}_{3}-\mathrm{CALB}$ and $\mathrm{SiO}_{2}-\mathrm{CH}_{3}-\mathrm{CALB} @ \mathrm{PDA}$ were taken into account. It can be seen from their adsorption-desorption curves, in Figure $4 \mathrm{~g}$, that they had strong interaction with $\mathrm{N}_{2}$ at low pressure and presented typical Langmuir type IV curves. The H2 hysteresis loops were also observed, indicating the mesoporous structure and the characteristics of 'ink bottle' pores [40]. From the pore size distribution curve in Figure $4 \mathrm{~h}$, it can be seen that the pore size $(15.02 \mathrm{~nm})$ and BET surface area $\left(165.84 \mathrm{~m}^{2} \cdot \mathrm{g}^{-1}\right)$ of $\mathrm{SiO}_{2}-\mathrm{CH}_{3}-\mathrm{CALB} @ P D A$ were larger than those of $\mathrm{SiO}_{2}-\mathrm{CH}_{3}-\mathrm{CALB}\left(13.52 \mathrm{~nm}\right.$ and $\left.121.67 \mathrm{~m}^{2} \cdot \mathrm{g}^{-1}\right)$, which we believe to be due to the PDA coatings and deposits on the surface of the $\mathrm{Si}-\mathrm{O}-\mathrm{Si}$ network structure during the sol-gel process, delaying the gel shrinkage [41].

The immobilization capacity of $\mathrm{SiO}_{2}-\mathrm{CH}_{3}-\mathrm{CALB} @ \mathrm{PDA}$ was evaluated by investigating the CALB loading. As shown in Figure 4i, the amount of CALB immobilized on $\mathrm{SiO}_{2}-\mathrm{CH}_{3}-\mathrm{CALB} @ \mathrm{PDA}$ increased with increasing CALB concentration. When the CALB concentration was $14.5 \mathrm{mg} / \mathrm{mL}$, the CALB loading increased to $45.6 \mathrm{mg} / \mathrm{g}$. However, when the CALB concentration was more than $14 \mathrm{mg} / \mathrm{mL}$, a decline in the activity recovery of the immobilized CALB was observed. The loading reached a maximum at a high enzyme concentration $(\sim 16 \mathrm{mg} / \mathrm{mL})$, and there is a slightly continuous decrease in the enzyme activity when the enzyme concentration exceeds $14.5 \mathrm{mg} / \mathrm{mL}$. This can be explained by the fact that excess CALB loading will easily lead to the congestion of the enzyme molecules. Therefore, the resulting spatial constraint can increase the mass transfer resistance of the 
substrate and product, which is expressed as reducing activity [42]. Therefore, the optimum CALB concentration was chosen as $14.5 \mathrm{mg} / \mathrm{mL}$. In this case, the CALB loading is efficient (activity recovery higher than $93 \%$ ) without sacrificing excess enzyme to unnecessary use. Meanwhile, compared with the enzyme loading of $28.5 \mathrm{mg} / \mathrm{g}$ on pristine $\mathrm{SiO}_{2}-\mathrm{CH}_{3}-\mathrm{CALB}$ at an initial CALB concentration of $14.5 \mathrm{mg} / \mathrm{mL}$, the enzyme loading on $\mathrm{SiO}_{2}-\mathrm{CH}_{3}-\mathrm{CALB} @ P D A$ reached as high as $45.6 \mathrm{mg} / \mathrm{g}$, nearly twice as high as that on $\mathrm{SiO}_{2}-\mathrm{CH}_{3}$-CALB. As mentioned above, the modification of PDA provided a barrier for the enzyme, and covalent linking enhanced the interaction between the enzyme and the support, effectively preventing enzyme leakage.

a

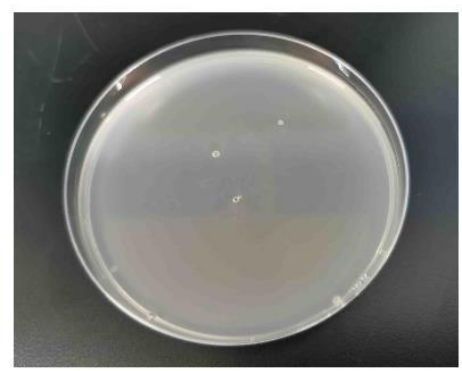

d
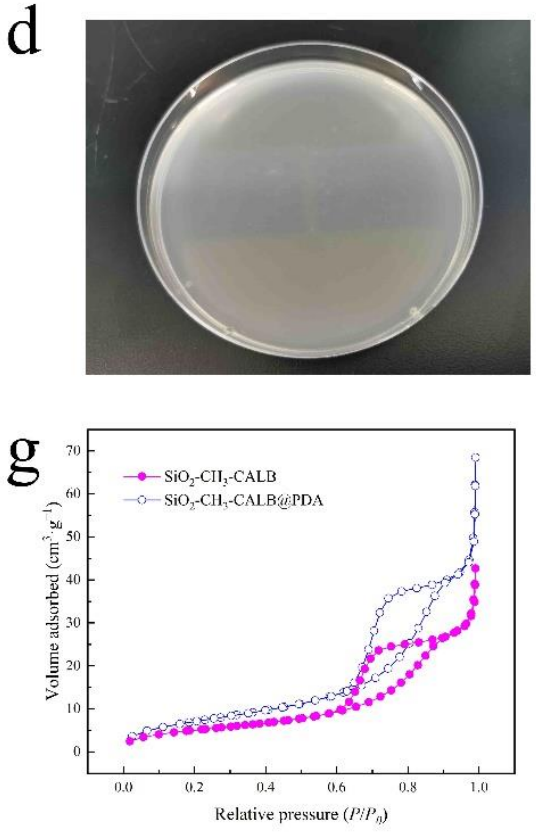

b

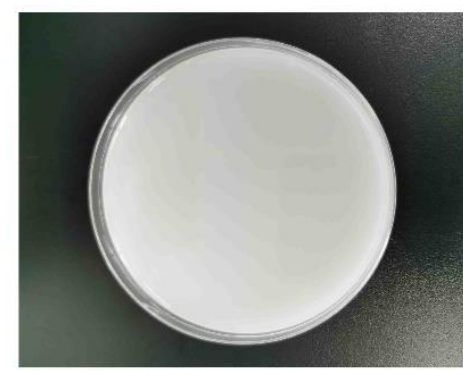

e

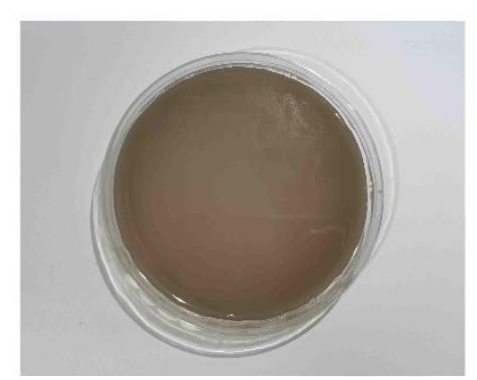

$\mathrm{h}$

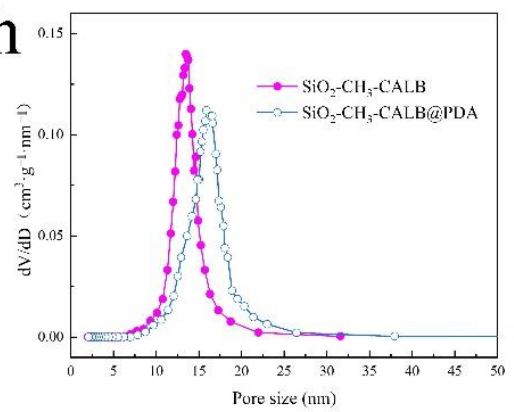

C

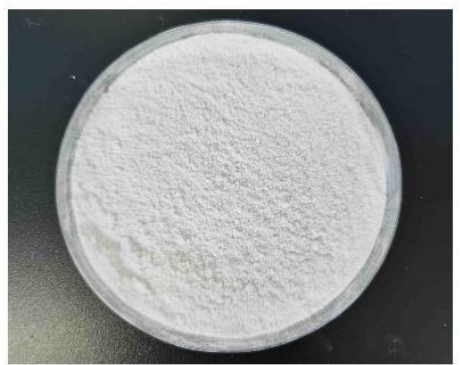

f

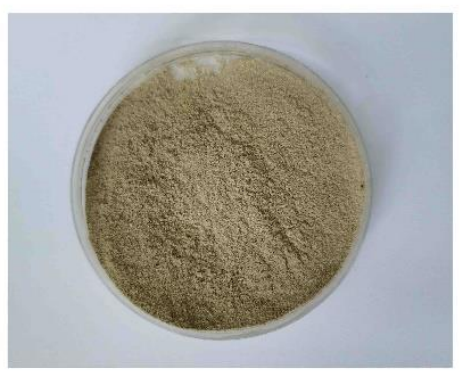

i

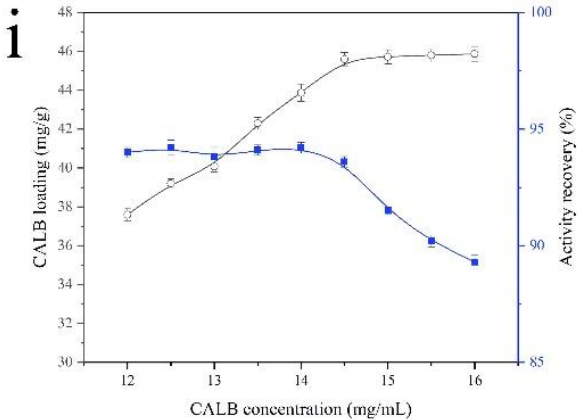

Figure 4. Sol-gel process of (a-c) $\mathrm{SiO}_{2}-\mathrm{CH}_{3}-\mathrm{CALB}$, (d-f) $\mathrm{SiO}_{2}-\mathrm{CH}_{3}-\mathrm{CALB} @ P D A,(\mathbf{g}$, h) pore structure and (i) enzyme loading.

\subsection{Strategy for Immobilizing CALB and Possible Mechanism}

Figure 5 shows the internal microstructure of the $\mathrm{SiO}_{2}-\mathrm{CH}_{3}-\mathrm{CALB}-$ and $\mathrm{SiO}_{2}-\mathrm{CH}_{3}-$ CALB@PDA-immobilized enzyme and the mechanism of the polydopamine-modified immobilized enzyme. The $\mathrm{Si}-\mathrm{O}-\mathrm{Si}$ polymer network skeleton was obtained by hydrolysis and a condensation reaction with TMOS and MTMS as co-precursors, and the enzyme molecules were embedded in the $\mathrm{Si}-\mathrm{O}-\mathrm{Si}$ network. In hydrolysis reaction, the methyl group of MTMS was not involved in hydrolysis, replacing and cross-linking with hydroxyl groups on $\mathrm{Si}-\mathrm{O}-\mathrm{Si}$ network, which provided a necessary condition for the development of hydrophobic properties [43]. The polydopamine-modified immobilized enzyme was based on the synergistic sol-gel mechanism [44]. In short, dopamine nanoparticles were uniformly mixed into the sol. In this system, dopamine hydrochloride was self-polymerized into PDA under alkaline conditions and deposited on the surface of $\mathrm{Si}-\mathrm{O}-\mathrm{Si}$ network. Moreover, the residual quinone functional groups presented in the polydopamine coat- 
ing were reactive toward nucleophilic groups, and CALB could couple covalently with polydopamine through Michael-type addition or Shiff-based formation [45,46]. We expected that the resulting $\mathrm{SiO}_{2}-\mathrm{CH}_{3}-\mathrm{CALB} @ \mathrm{PDA}$ xerogels would have excellent mechanical strengths and enzyme activity stabilities.
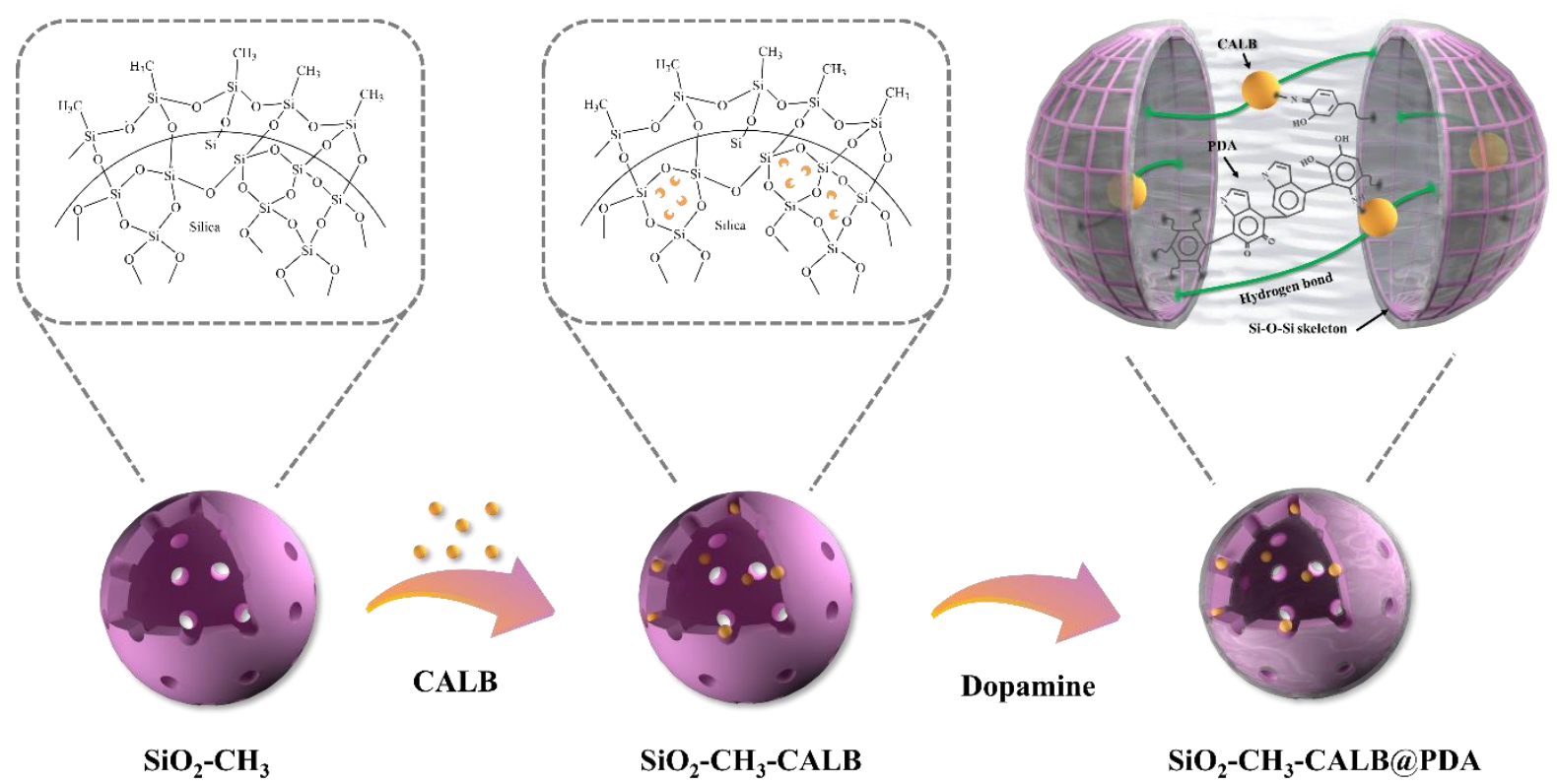

Dopamine

$\mathrm{SiO}_{2}-\mathrm{CH}_{3}-\mathrm{CALB} @ \mathrm{PDA}$

Figure 5. The internal microstructures of $\mathrm{SiO}_{2}-\mathrm{CH}_{3}-\mathrm{CALB}$ and $\mathrm{SiO}_{2}-\mathrm{CH}_{3}-\mathrm{CALB} @ P D A$ and the possible mechanism of the polydopamine-modified immobilized enzyme.

\subsection{Mechanical Properties}

In practical applications, xerogel is prone to deformation under external force, resulting in enzyme leakage or inactivation. Therefore, strength is crucial for the application of xerogel in organic catalysis. We experimentally compared the strengths of $\mathrm{SiO}_{2}-\mathrm{CH}_{3}-\mathrm{CALB}$ and $\mathrm{SiO}_{2}-\mathrm{CH}_{3}-\mathrm{CALB} @ P D A$. The compressive stress-strain curves for $\mathrm{SiO}_{2}-\mathrm{CH}_{3}-\mathrm{CALB}$ and $\mathrm{SiO}_{2}-\mathrm{CH}_{3}-\mathrm{CALB} @ \mathrm{PDA}$ are presented in Figure 6. A macroscopic compression experiment showed that the $\mathrm{SiO}_{2}-\mathrm{CH}_{3}-\mathrm{CALB} @ \mathrm{PDA}$ xerogel model could withstand higher pressures $(12.55 \mathrm{Mpa})$ than that of $\mathrm{SiO}_{2}-\mathrm{CH}_{3}-\mathrm{CALB}(9.00 \mathrm{Mpa})$, and the strain of $\mathrm{SiO}_{2}-$ $\mathrm{CH}_{3}$-CALB@PDA (9.64\%) was greater than that of $\mathrm{SiO}_{2}-\mathrm{CH}_{3}-\mathrm{CALB}(9.07 \%)$. In addition, the fracture modes of the two materials were also significantly different. The fracture mode of $\mathrm{SiO}_{2}-\mathrm{CH}_{3}$-CALB was similar to that of brittle materials, while the fracture mode of $\mathrm{SiO}_{2}-\mathrm{CH}_{3}-\mathrm{CALB} @ \mathrm{PDA}$ was similar to that of viscoelastic materials $[47,48]$. This can be ascribed to two factors. On the one hand, PDA was deposited on the surface of the $\mathrm{Si}-\mathrm{O}-\mathrm{Si}$ network, which reduced the capillary force generated by the shrinkage of the xerogel during drying [29]. On the other hand, the surface of the PDA contained a large number of functional groups that could interact with $\mathrm{Si}-\mathrm{O}-\mathrm{Si}$ chains, serving as crosslinking sites to increase the mechanical strength of the $\mathrm{SiO}_{2}-\mathrm{CH}_{3}$-CALB@PDA xerogel, preventing it from breaking under pressure [32]. Overall, the internal network structure of the xerogel and polydopamine coatings played a key role in the whole compression process, confirming the formation of a stable xerogel. After modification by PDA nanoparticles, the mechanical properties of the xerogels were improved. This occurred because polydopamine can interact with the xerogel matrix, increasing xerogel hardness and improving brittleness. 


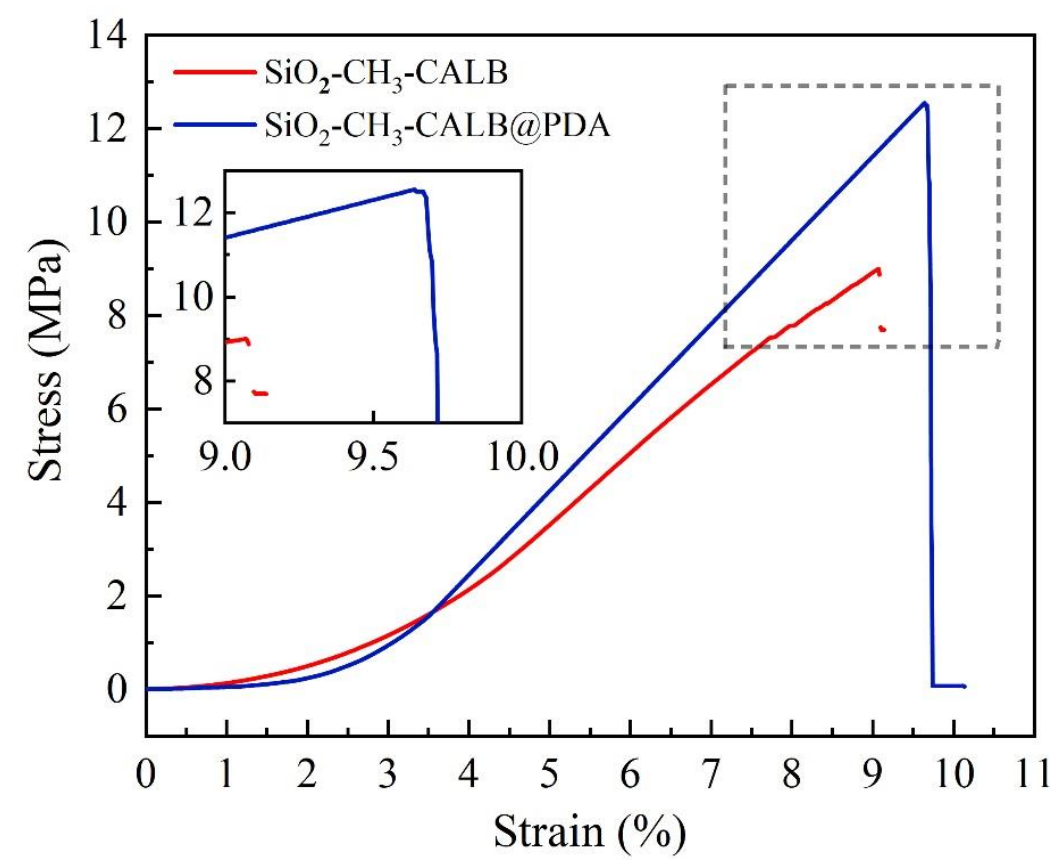

Figure 6. Stress-strain curves of $\mathrm{SiO}_{2}-\mathrm{CH}_{3}-\mathrm{CALB}$ and $\mathrm{SiO}_{2}-\mathrm{CH}_{3}-\mathrm{CALB} @ P D A$.

\subsection{Stability of Immobilized CALB}

The free and immobilized CALB was incubated at $60^{\circ} \mathrm{C}$ for a certain time to investigate their thermal stability. The influence of temperature towards the stability of CALB is illustrated in Figure 7a. With the increasing of incubation time, the hydrolytic activity of free $\mathrm{CALB}$ and $\mathrm{SiO}_{2}-\mathrm{CH}_{3}-\mathrm{CALB}$ decreased, and free CALB was entirely deactivation after $3 \mathrm{~h}$ treatment. However, the $\mathrm{SiO}_{2}-\mathrm{CH}_{3}-\mathrm{CALB} @ P D A$ exhibited better stability, which maintained $36.5 \%$ of its activity after $6 \mathrm{~h}$ of incubation. These results revealed that the better thermal stability of $\mathrm{SiO}_{2}-\mathrm{CH}_{3}-\mathrm{CALB} @ P D A$ among free CALB and $\mathrm{SiO}_{2}-\mathrm{CH}_{3}-\mathrm{CALB}$ was attributed to the strong covalent bonds that formed through the reaction between the amine in the enzyme and the electrophilic groups in the PDA [49]. In addition, the PDA layer provides a stiffer external backbone to protect the CALB molecule from high temperatures [50]. Improvements in thermal stability will expand the range of applications for immobilized enzymes.

In order to investigate the storage stability of $\mathrm{SiO}_{2}-\mathrm{CH}_{3}-\mathrm{CALB}$ and $\mathrm{SiO}_{2}-\mathrm{CH}_{3}-\mathrm{CALB} @ \mathrm{PDA}$, the examination was carried out at room temperature for 90 days. As shown in Figure $7 \mathrm{~b}$, $\mathrm{SiO}_{2}-\mathrm{CH}_{3}-\mathrm{CALB}$ exhibited $66.3 \%$ of its initial activity after 90 days, while $\mathrm{SiO}_{2}-\mathrm{CH}_{3}-$ CALB@PDA exhibited approximately $71.4 \%$ under the same conditions. The high storage stability exhibited by CALB can be explained by the protective effect of the $\mathrm{Si}-\mathrm{O}-\mathrm{Si}$ network in the silica structure, which protects the enzyme activity inside, and further enhances its structural stability. The interactions of different geometries of the enzyme and support may have a significant influence on the enzyme activity. Generally, it is accepted that the highly curved surface reduces the possibility of enzyme denaturation and inhibits lateral interactions between adjacent enzymes, further leading to the structural stability and persistent activity of the adsorbed enzyme [51,52]. Additionally, multiple points of binding were observed between the PDA support and CALB in $\mathrm{SiO}_{2}-\mathrm{CH}_{3}-\mathrm{CALB} @ P D A$, which formed the PDA coating on the surface of the polymer network inside the xerogels, acting in a protective role $[53,54]$; this could explain their greater activity in external environments. 
a

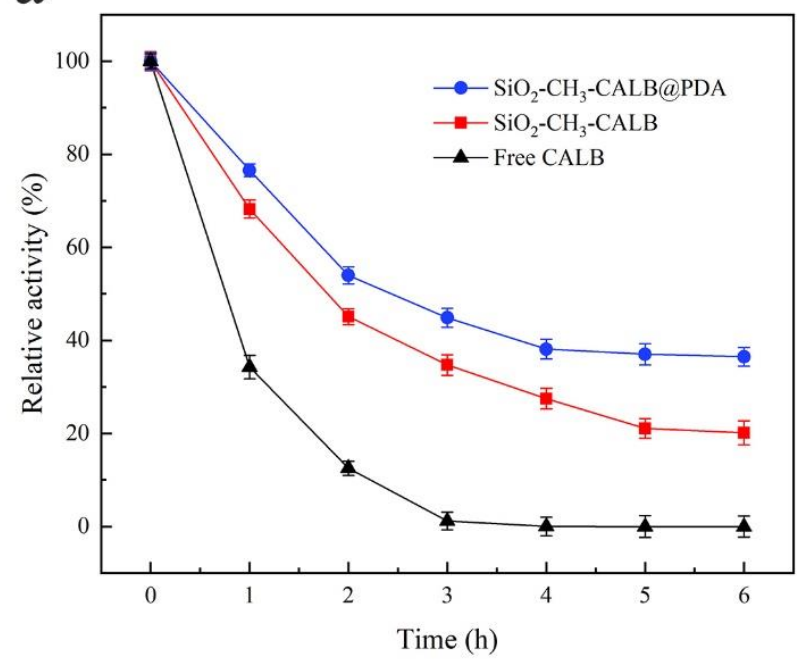

b

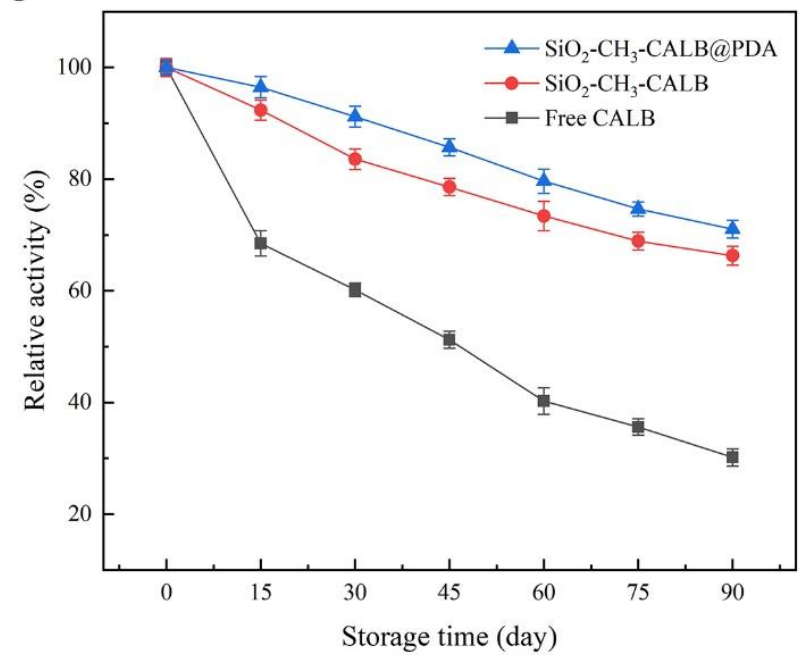

Figure 7. Thermal stability at $60{ }^{\circ} \mathrm{C}(\mathbf{a})$ and storage stability at $25{ }^{\circ} \mathrm{C}(\mathbf{b})$ of free $\mathrm{CALB}, \mathrm{SiO}_{2}-\mathrm{CH}_{3}-\mathrm{CALB}$ and $\mathrm{SiO}{ }_{2}-$ $\mathrm{CH}_{3}$-CALB@PDA.

\subsection{Transesterification and Reusability}

Some enzymes have been used as biocatalysts to synthetize ester compounds, among which CALB can form high value-added ester products by transesterification reactions. As one of the major biocatalysts for ester synthesis, CALB can catalyze the transesterification of $n$-butanol with ethyl acetate to produce butyl acetate, which is an excellent organic solvent. Figure 8 shows the CALB-catalyzed synthesis of butyl acetate by transesterification of $n$-butanol with ethyl acetate. The reaction is a solvent-free system, and was carried out in a batch reactor at $70{ }^{\circ} \mathrm{C}$. In a solvent-free system, the enzyme directly acts on the substrate, increases the substrate concentration, improving the reaction rate and selectivity and reducing the damage of organic solvents to the enzyme [55]. Therefore, we chose ethyl acetate as a reactant, as it also acts as a solvent in the CALB-catalyzed synthesis of butyl acetate.<smiles>CCCCO</smiles>

$n$-butanol

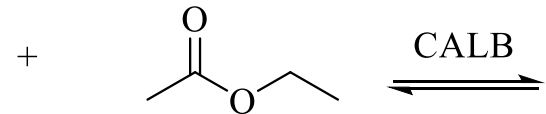

ethyl acetate<smiles>CCCCOC(C)=O</smiles>

butyl acetate<smiles>CCO</smiles>

ethanol

Figure 8. The reaction diagram of butyl acetate synthesis catalyzed by CALB.

The transesterification of $n$-butanol with ethyl acetate was selected as a target reaction to evaluate the conversion efficiency and reusability of immobilized CALB in the present work. The conversion of $n$-butanol and the reusability of $\mathrm{SiO}_{2}-\mathrm{CH}_{3}-\mathrm{CALB}$ and $\mathrm{SiO}_{2}-\mathrm{CH}_{3}-$ CALB@PDA were compared under optimal active conditions. As shown in Figure 9, in the first cycle, the conversion of $n$-butanol of $\mathrm{SiO}_{2}-\mathrm{CH}_{3}-\mathrm{CALB}$ and $\mathrm{SiO}_{2}-\mathrm{CH}_{3}-\mathrm{CALB} @ P D A$ retained $52.42 \%$ and $57.67 \%$, respectively. For $\mathrm{SiO}_{2}-\mathrm{CH}_{3}-\mathrm{CALB}, \mathrm{CALB}$ molecules were encapsulated in the xerogel polymer network by physical adsorption, Virgen-Ortíz et al. have reported some substrates/product may produce the enzyme's release from physically absorbed enzymes, so the leakage of CALB was prone to denaturation or inactivation during the reaction [56]. The decrease in conversion was observed in the first five cycles. After the fifth cycle, the activity began a slow deceleration state, lasting for the next three cycles. After eight cycles, $\mathrm{SiO}_{2}-\mathrm{CH}_{3}-\mathrm{CALB} @ P D A$ retained more than a $30.84 \%$ conversion of $n$-butanol. $\mathrm{SiO}_{2}-\mathrm{CH}_{3}-\mathrm{CALB}$ retained a $25.04 \%$ conversion of $n$-butanol. The conversion 
of $n$-butanol loss could be due to enzyme leakage during washing and enzyme deactivation during repeated uses [57]. As the reaction produces a by-product of ethanol in the batch reactor system, resulting in enzyme inhibition, inhibition will reduce lipase activity. High concentrations of $n$-butanol inhibit the synthesis of butyl acetate catalyzed by immobilized CALB. This inhibitory effect has been found in the reaction among butyric acid and lauric acid with ethanol $[58,59]$. Therefore, operational stability of the enzyme is not too high. Considering $\mathrm{SiO}_{2}-\mathrm{CH}_{3}-\mathrm{CALB} @ \mathrm{PDA}$ had better reusability, storage stability and mechanical strength, $\mathrm{SiO}_{2}-\mathrm{CH}_{3}-\mathrm{CALB} @ \mathrm{PDA}$ is more applicable for practical applications.

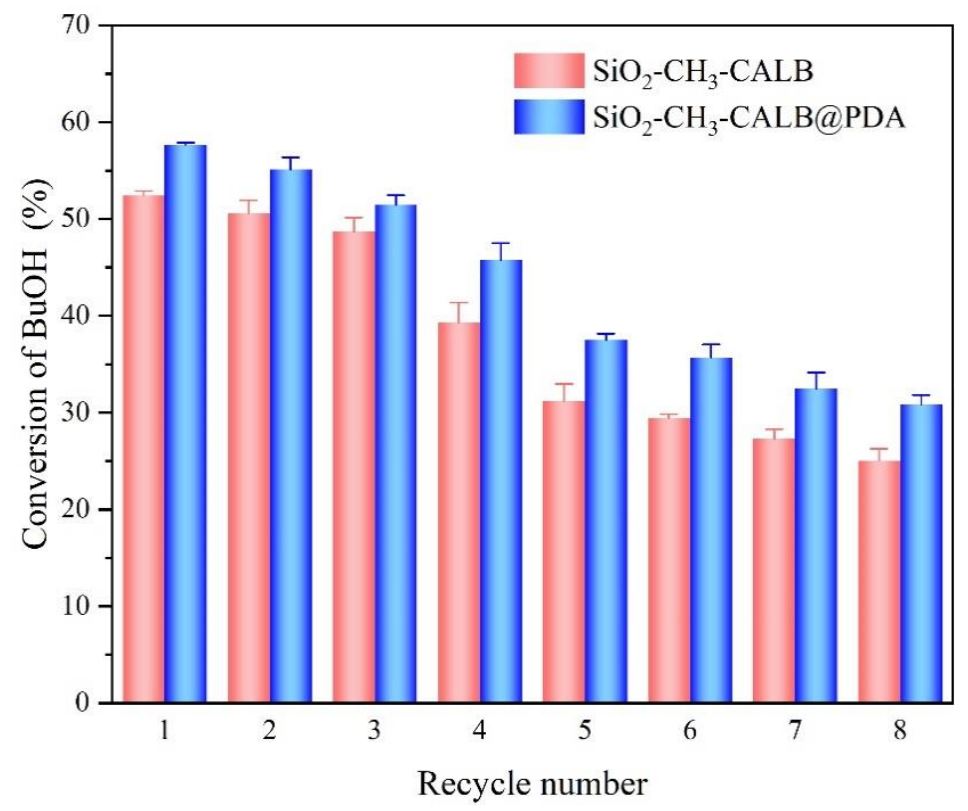

Figure 9. Conversion of $n$-butanol and repeatability of $\mathrm{SiO}_{2}-\mathrm{CH}_{3}-\mathrm{CALB}$ and $\mathrm{SiO}_{2}-\mathrm{CH}_{3}-\mathrm{CALB} @ P D A$.

\subsection{Comparison of Butyl Acetate Production Using Previous Lipase Biocatalysts}

The prepared catalyst of $\mathrm{SiO}_{2}-\mathrm{CH}_{3}-\mathrm{CALB} @ P D A$ possessed the advantages of biocompatibility, environmental friendliness, operating convenience and safety. Compared with previous lipase catalysts, such as $\mathrm{SiO}_{2}-\mathrm{CH}_{3}-\mathrm{CALB}$ and Novozyme 435 , the catalytic efficiency of $\mathrm{SiO}_{2}-\mathrm{CH}_{3}-\mathrm{CALB} @ \mathrm{PDA}(57.67 \%)$ in the transesterification reaction system was slightly higher than those of $\mathrm{SiO}_{2}-\mathrm{CH}_{3}-\mathrm{CALB}(52.42 \%)$ and Novozyme 435 (55.30\%) [60]. Although the improvement in operational stability and catalytic performance is not obvious, the polydopamine modification strategy is worth adopting; it can improve the immobilized enzyme loading and balance the mechanical properties of the supports, which expands the application range of immobilized enzymes in some special cases.

\section{Experimental Section}

\subsection{Materials}

Tetramethoxysilane (TMOS), methyltrimethoxysilane (MTMS), methanol (MeOH), sodium fluoride $(\mathrm{NaF})$, polyethylene glycol (PEG, MW 400), dopamine hydrochloride, 4-nitrophenyl palmitate ( $P$-NPP), Coomassie Brilliant Blue G250, bovine serum albumin ( $\geq 96 \%$ ), $n$-butanol, ethyl acetate, $n$-propanol and sodium-phosphate buffer (PBS, $0.1 \mathrm{M}$, $\mathrm{pH}$ 7.5) were purchased from Aladdin (Shanghai, China). Candida antarctica lipase B (CALB) was provided from Novozymes (Copenhagen, Denmark) with a free enzyme activity of $510 \mathrm{U} \cdot \mathrm{g}^{-1}$. All reagents except bovine serum albumin were analytically pure without further purification.

\subsection{Preparation of $\mathrm{SiO}_{2}-\mathrm{CH}_{3}-\mathrm{CALB}$}

$\mathrm{SiO}_{2}-\mathrm{CH}_{3}-\mathrm{CALB}$ was prepared by sol-gel method. Firstly, TOMS (0.54 g), MTMS (1.934 g), methanol (3.39 g), PEG (0.14 g), NaF solution (0.49 g, $1 \mathrm{M})$, water (1.26 g) and 
CALB enzyme solution (3.39 g) were mixed and stirred at $0{ }^{\circ} \mathrm{C}$, and the mixture was transferred to a clean petri dish. Then, the petri dish was sealed and placed at room temperature for $2 \mathrm{~h}$ to form a gel network. Finally, the petri dish was opened to evaporate the water and solvent in the gel completely, and then dried at room temperature for $48 \mathrm{~h}$.

\subsection{Preparation of $\mathrm{SiO}_{2}-\mathrm{CH}_{3}-\mathrm{CALB} @ P D A$}

Dopamine hydrochloride (0.02 g) was dispersed in methanol (3.39 g), then NaF solution $(0.98 \mathrm{~g}, 1 \mathrm{M})$ was added and mixed for $10 \mathrm{~min}$. The use of NaF solution rather than Tris buffer was due to the fact that primary amine group in Tris can covalently interact with PDA, which could affect the deposition of PDA and the continuous coupling of CALB with PDA.

To the obtained mixture we added TMOS $(0.54 \mathrm{~g})$ and $1.934 \mathrm{~g}$ of MTMS (1.934 $\mathrm{g})$, PEG $(0.14 \mathrm{~g})$, water $(1.26 \mathrm{~g})$ and CALB enzyme solution $(3.39 \mathrm{~g})$, which was then mixed and stirred at $0{ }^{\circ} \mathrm{C}$, and the mixture was transferred to a clean petri dish. Then, the petri dish was sealed and placed at room temperature for $4 \mathrm{~h}$ to form a gel network. Finally, the petri dish was opened to evaporate the water and solvent in the gel completely and then dried at room temperature for $48 \mathrm{~h}$.

\subsection{Characterization}

The microstructures of the samples were observed using a transmission electron microscope (TEM, Talos F200S, Hillsboro, FL, USA) and scanning electron microscopy (SEM, Nova Nano SEM 450, Hillsboro, FL, USA). Fourier transform infrared (FT-IR) spectra of the samples were collected from 4000 to $400 \mathrm{~cm}^{-1}$ on a Bruker Tensor 27 analyzer (Bremen, Germany) using $\mathrm{KBr}$ pellets method. X-ray diffraction (XRD) patterns were measured by a Bruker D8 Discover (Bremen, Germany) with scanning rate of $6^{\circ} \mathrm{min}^{-1}$ under $\mathrm{Cu} K \alpha$ radiation $(\lambda=0.154056 \mathrm{~nm})$. Samples were mounted on a low background silicon substrate and diffraction scans covered a $2 \theta$ range of $5^{\circ}$ to $80^{\circ}$. X-ray photoelectron spectra (XPS, Al-K $\alpha$ ) were recorded on an X-ray photoelectron spectrometer (ESCALAB 250Xi, Hillsboro, FL, USA), and the C $1 \mathrm{~s}$ of $284.8 \mathrm{eV}$ was referred to for calibrating the binding energy. The $\mathrm{N}_{2}$ adsorption-desorption isotherms were measured by a pore sizespecific surface area analyzer (SSA-6000, Beijing, China) at $77 \mathrm{~K}$. The pore size distribution and surface area were determined through calculating $\mathrm{N}_{2}$ adsorption-desorption according to the Brunauer-Emmett-Teller (BET) method. A spectrophotometer (UV-2600, Shimadzu, Kyoto, Japan) was used to analyze the concentration and activity of the enzyme.

\subsection{Determination of Enzyme Loading}

The Bradford method was used to determine enzyme embedding in the silica xerogels by measuring of the protein concentrations in the initial enzyme solutions and immobilized enzyme phosphate detergents. A calibration curve was plotted, using Coomassie Brilliant Blue G-250 solutions as standards. The enzyme concentration in the solution was able to be determined with UV-vis spectrophotometry, by measuring the absorbance at $595 \mathrm{~nm}$. The amount of enzyme embedded in silica xerogels was calculated by the following equation:

$$
\text { enzymeloading }=\frac{C_{0}-C_{1}}{C_{0}} \times 100 \%
$$

where $C_{0}$ is the initial enzyme concentration $(\mathrm{mg} / \mathrm{g}), C_{1}$ is the enzyme concentration in phosphate detergent $(\mathrm{mg} / \mathrm{g})$.

\subsection{Properties of Free CALB and the Immobilized CALB}

\subsubsection{Assay of the CALB Activity}

The free CALB and samples of immobilized CALB activities were determined by using $p$-NPP ( $5 \mathrm{mg} / \mathrm{mL}$ in ethanol) as the substrate. Typically, $200 \mu \mathrm{L}$ of $p$-NPP solution was added to the solution consisting of the samples $(2 \mathrm{mg})$ and PBS (0.1 M, pH 7.5, $3 \mathrm{~mL})$. After reaction for $3 \mathrm{~min}$, the filtrate of the reaction that contained 4-nitrophenol ( $p$-NP), and 
the concentration of $p$-NP was quantified via absorbance at $410 \mathrm{~nm}$ on a spectrophotometer. One unit (U) of lipase hydrolytic activity was regard as the lipase mass that liberates 1 nmol of $p$-NP under these test conditions per minute. The relative enzymatic activity was related to a percentage of this highest activity $(100 \%$ means the highest enzymatic activity). The activity recovery was calculated from the value of the activity of the initial CALB solution divided by the activity value of immobilized CALB obtained immediately after the immobilization procedure.

\subsubsection{Thermal and Storage Stability of the Free CALB and Immobilized CALB}

Free CALB, $\mathrm{SiO}_{2}-\mathrm{CH}_{3}-\mathrm{CALB}$ and $\mathrm{SiO}_{2}-\mathrm{CH}_{3}-\mathrm{CALB} @ P D A$ were incubated in PBS (50 mM, pH 7.5) at $70{ }^{\circ} \mathrm{C}$ for $6 \mathrm{~h}$ to examine their thermal stabilities. The $p$-NPP assay was employed to measure residual activity as described in Section 3.6.1. To evaluate the storage stability, the residual activity of $\mathrm{SiO}_{2}-\mathrm{CH}_{3}-\mathrm{CALB}$ and $\mathrm{SiO}_{2}-\mathrm{CH}_{3}-\mathrm{CALB} @ P D A$ was tested after a given treatment duration at $25^{\circ} \mathrm{C}$, respectively. The residual activity of each sample under treatment was measured at given time intervals and used for comparison with the original activity.

\subsection{Mechanical Performance Tests}

The mechanical performances of $\mathrm{SiO}_{2}-\mathrm{CH}_{3}-\mathrm{CALB}$ and $\mathrm{SiO}_{2}-\mathrm{CH}_{3}-\mathrm{CALB} @ P D A$ were tested using a microcomputer control electron universal testing machines (CMT6104, Shenzhen, China) with a 5000-N load cell. To facilitate testing, samples were made into rectangular specimens. Compression strain tests of the samples (lengths, $23 \mathrm{~mm}$; widths, $13.28 \mathrm{~mm}$; thicknesses, $6 \mathrm{~mm}$ ) were performed at a compression rate of $2 \mathrm{~mm} / \mathrm{min}$.

\subsection{Transesterification and Reusability}

The reaction for the transesterification of $n$-butanol with ethyl acetate was performed in a glass three-necked reactor with a volume of $250 \mathrm{~mL}$ at $343 \mathrm{~K}$ and $101.3 \mathrm{kPa}$. The electric stirring was controlled up to $3000 \mathrm{rpm}$ to achieve uniform mixing of the reactive mixture. In the experiment, the mixture of reactants ethyl acetate and $n$-butanol (molar ratio of ethyl acetate to $n$-butanol was $1: 1$ ) were heated to $343 \mathrm{~K}$ in a water bath, then the catalysts (the catalyst dosage was $10 \%$ of the mass of $n$-butanol, and the catalysts were $\mathrm{SiO}_{2}-\mathrm{CH}_{3}-\mathrm{CALB}$ and $\left.\mathrm{SiO}_{2}-\mathrm{CH}_{3}-\mathrm{CALB} @ \mathrm{PDA}\right)$ were set in the reactor to start the reaction. Samples were withdrawn from the reactor every $30 \mathrm{~min}$ with a syringe during the reaction for composition analysis until the $5 \mathrm{~h}$. Finally, the catalysts were washed with PBS (0.1 M, $\mathrm{pH} 7.5$ ) buffer and dried for $12 \mathrm{~h}$ before next cycle.

The composition of the product was analyzed by gas chromatography (GC-2010 Pro, Shimadzu, Kyoto, Japan) equipped with a flame ionization detector (FID) and an InertCap FFAP capillary column $(30 \mathrm{~m} \times 0.25 \mathrm{~mm} \times 0.25 \mathrm{~mm})$. Typically, $n$-propanol was used as the internal standard substance. $\mathrm{N}_{2}$ with purity of $99.99 \mathrm{wt} \%$ was used as carrier gas at $1 \mathrm{~mL} / \mathrm{min}$. The temperature of the injection port and the detector were controlled at $473 \mathrm{~K}$ and $493 \mathrm{~K}$, respectively. $0.4 \mu \mathrm{L}$ sample was injected each time.

\section{Conclusions}

In this work, the immobilization of CALB in PDA-modified silica xerogels was successfully prepared by the self-polymerization of dopamine on the $\mathrm{Si}-\mathrm{O}-\mathrm{Si}$ network surfaces of silica xerogels. The modified silica xerogels showed an excellent embedding ability for CALB compared with conventional silica xerogels. They exhibited a high capacity of $45.6 \mathrm{mg} / \mathrm{g}_{\text {support }}$ for CALB encapsulation. The mechanical strength and thermal and storage stability of the immobilized CALB were greatly elevated. Moreover, the immobilization of an enzyme in PDA-modified silica xerogels was utilized in the transesterification between $n$-butanol with ethyl acetate, which retained $30.84 \%$ conversion of $n$-butanol after eight cycles. In short, the $\mathrm{SiO}_{2}-\mathrm{CH}_{3}-\mathrm{CALB} @ P D A$ catalyst was prepared by a simple and practical method, which is expected to overcome the related problems of shrinkage and 
weak binding force in conventional silica xerogels, and it has great application potential in the field of industrial catalysis.

Author Contributions: Conceptualization, H.W. and W.S.; methodology, H.W. and W.S.; validation, H.W., W.Y. and S.Z.; formal analysis, H.W.; investigation, H.W., W.Y.; resources, H.W.; data curation, Y.Z.; writing—original draft preparation, W.Y.; writing—review and editing, H.W., W.Y., Y.Z., C.L. and W.S.; visualization, H.W. and W.Y.; supervision, W.S.; project administration, W.S.; funding acquisition, H.W., W.S. All authors have read and agreed to the published version of the manuscript.

Funding: This research was funded by financial support of National Natural Science Foundation of China (No. 21878066 and No. 21878068), National Natural Science Foundation of Hebei Province (No. B2020202015) and Special Correspondent Project of Tianjin (No. 18JCTPJC56500).

Conflicts of Interest: The authors declare no conflict of interest.

\section{References}

1. Mathpati, A.C.; Kalghatgi, S.G.; Mathpati, C.S.; Bhanage, B.M. Immobilized lipase catalyzed synthesis of n-amyl acetate: Parameter optimization, heterogeneous kinetics, continuous flow operation and reactor modeling. J. Chem. Technol. Biotechnol. 2018, 93, 2906-2916. [CrossRef]

2. Sanfilippo, C.; Paternò, A.A.; Patti, A. Resolution of racemic amines via lipase-catalyzed benzoylation: Chemoenzymatic synthesis of the pharmacologically active isomers of labetalol. Mol. Catal. 2018, 449, 79-84. [CrossRef]

3. Kuo, C.H.; Chen, H.H.; Chen, J.H.; Liu, Y.C.; Shieh, C.J. High yield of wax ester synthesized from cetyl alcohol and octanoic acid by lipozyme RMIM and Novozym 435. Int. J. Mol. Sci. 2012, 13, 11694-11704. [CrossRef] [PubMed]

4. Chojnacka, A.; Gładkowski, W. Production of structured phosphatidylcholine with high content of myristic acid by lipasecatalyzed acidolysis and interesterification. Catalysts 2018, 8, 281. [CrossRef]

5. Zhang, H.; Liu, T.; Zhu, Y.; Hong, L.; Li, T.; Wang, X.; Fu, Y. Lipases immobilized on the modified polyporous magnetic cellulose support as an efficient and recyclable catalyst for biodiesel production from Yellow horn seed oil. Renew. Energy 2020, 145, 1246-1254. [CrossRef]

6. Gao, J.; Kong, W.; Zhou, L.; He, Y.; Ma, L.; Wang, Y.; Yin, L.; Jiang, Y. Monodisperse core-shell magnetic organosilica nanoflowers with radial wrinkle for lipase immobilization. Chem. Eng. J. 2017, 309, 70-79. [CrossRef]

7. Fernandez-Lopez, L.; Pedrero, S.G.; Lopez-Carrobles, N.; Gorines, B.C.; Virgen-Ortiz, J.J.; Fernandez-Lafuente, R. Effect of protein load on stability of immobilized enzymes. Enzym. Microb. Technol. 2017, 98, 18-25. [CrossRef]

8. Gascon, V.; Diaz, I.; Blanco, R.M.; Marquez-Alvarez, C. Hybrid periodic mesoporous organosilica designed to improve the properties of immobilized enzymes. RSC Adv. 2014, 4, 34356-34368. [CrossRef]

9. Arana-Peña, S.; Rios, N.S.; Carballares, D.; Gonçalves, L.R.B.; Fernandez-Lafuente, R. Immobilization of lipases via interfacial activation on hydrophobic supports: Production of biocatalysts libraries by altering the immobilization conditions. Catal. Today. 2021, 362, 130-140. [CrossRef]

10. Manoel, E.A.; Dos Santos, J.C.S.; Freire, D.M.G.; Rueda, N.; Fernandez-Lafuente, R. Immobilization of lipases on hydrophobic supports involves the open form of the enzyme. Enzym. Microb. Technol. 2015, 71, 53-57. [CrossRef]

11. Xue, C.; Wang, J.; Tu, B.; Zhao, D. Hierarchically Porous Silica with Ordered Mesostructure from Confinement Self-Assembly in Skeleton Scaffolds. Chem. Mater. 2009, 22, 494-503. [CrossRef]

12. Wu, D.; Xu, F.; Sun, B.; Fu, R.; He, H.; Matyjaszewski, K. Design and preparation of porous polymers. Chem. Rev. 2012, 112, 3959-4015. [CrossRef]

13. Hwang, E.T.; Gu, M.B. Enzyme stabilization by nano/microsized hybrid materials. Eng. Life Sci. 2013, 13, 49-61. [CrossRef]

14. Znaidi, L. Sol-gel-deposited ZnO thin films: A review. Mater. Sci. Eng. B 2010, 174, 18-30. [CrossRef]

15. Vinogradov, V.V.; Avnir, D. Exceptional thermal stability of therapeutical enzymes entrapped in alumina sol-gel matrices. J. Mater. Chem. B 2014, 2, 2868-2873. [CrossRef] [PubMed]

16. Pierre, A.C. The sol-gel encapsulation of enzymes. Biocatal. Biotransform. 2009, 22, 145-170. [CrossRef]

17. Rivas Murillo, J.S.; Bachlechner, M.E.; Campo, F.A.; Barbero, E.J. Structure and mechanical properties of silica aerogels and xerogels modeled by molecular dynamics simulation. J. Non-Cryst. Solids. 2010, 356, 1325-1331. [CrossRef]

18. Wang, H.; Liu, W.; Gao, L.; Lu, Y.; Chen, E.; Xu, Y.; Liu, H. Synthesis of n-butyl acetate via reactive distillation column using Candida Antarctica lipase as catalyst. Bioproc. Biosyst. Eng. 2020, 43, 593-604. [CrossRef]

19. Latella, B.A.; Ignat, M.; Barbé, C.J.; Cassidy, D.J.; Li, H. Cracking and Decohesion of Sol-Gel Hybrid Coatings on Metallic Substrates. J. Sol-Gel. Sci. Technol. 2004, 31, 143-149. [CrossRef]

20. Yan, M.; Ge, J.; Liu, Z.; Ouyang, P. Encapsulation of single enzyme in nanogel with enhanced biocatalytic activity and stability. J. Am. Chem. Soc. 2006, 128, 11008-11009. [CrossRef]

21. Lee, H.R.; Chung, M.; Kim, M.I.; Ha, S.H. Preparation of glutaraldehyde-treated lipase-inorganic hybrid nanoflowers and their catalytic performance as immobilized enzymes. Enzym. Microb. Technol. 2017, 105, 24-29. [CrossRef]

22. Rodrigues, E.G.; Pereira, M.F.R.; Órfão, J.J.M. Glycerol oxidation with gold supported on carbon xerogels: Tuning selectivities by varying mesopore sizes. Appl. Catal. B 2012, 115, 1-6. [CrossRef] 
23. Huang, Q.; Chen, J.; Liu, M.; Huang, H.; Zhang, X.; Wei, Y. Polydopamine-based functional materials and their applications in energy, environmental, and catalytic fields: State-of-the-art review. Chem. Eng. J. 2020, 387, 124019. [CrossRef]

24. Cheng, W.; Zeng, X.; Chen, H.; Li, Z.; Zeng, W.; Mei, L.; Zhao, Y. Versatile Polydopamine Platforms: Synthesis and Promising Applications for Surface Modification and Advanced Nanomedicine. ACS Nano. 2019, 13, 8537-8565. [CrossRef] [PubMed]

25. Zhang, C.; Gong, L.; Mao, Q.; Han, P.; Lu, X.; Qu, J. Laccase immobilization and surface modification of activated carbon fibers by bio-inspired poly-dopamine. RSC Adv. 2018, 8, 14414-14421. [CrossRef]

26. Samyn, P. A platform for functionalization of cellulose, chitin/chitosan, alginate with polydopamine: A review on fundamentals and technical applications. Int. J. Biol. Macromol. 2021, 178, 71-93. [CrossRef] [PubMed]

27. Kang, S.M.; Hwang, N.S.; Yeom, J.; Park, S.Y.; Messersmith, P.B.; Choi, I.S.; Langer, R.; Anderson, D.G.; Lee, H. One-Step Multipurpose Surface Functionalization by Adhesive Catecholamine. Adv. Funct. Mater. 2012, 22, 2949-2955. [CrossRef]

28. Lee, H.; Scherer, N.F.; Messersmith, P.B. Single-molecule mechanics of mussel adhesion. Proc. Natl. Acad. Sci. USA 2006, 103, 12999-13003. [CrossRef] [PubMed]

29. Fidalgo, A.; Ilharco, L.M. Correlation between physical properties and structure of silica xerogels. J. Non-Cryst. Solids 2004, 347, 128-137. [CrossRef]

30. Jiang, Y.; Wang, Y.; Wang, H.; Zhou, L.; Gao, J.; Zhang, Y.; Zhang, X.; Wang, X.; Li, J. Facile immobilization of enzyme on three dimensionally ordered macroporous silica via a biomimetic coating. N. J. Chem. 2015, 39, 978-984. [CrossRef]

31. Qu, K.; Zheng, Y.; Dai, S.; Qiao, S.Z. Graphene oxide-polydopamine derived N,S-codoped carbon nanosheets as superior bifunctional electrocatalysts for oxygen reduction and evolution. Nano Energy 2016, 19, 373-381. [CrossRef]

32. Zeng, Q.; Qian, Y.; Huang, Y.; Ding, F.; Qi, X.; Shen, J. Polydopamine nanoparticle-dotted food gum hydrogel with excellent antibacterial activity and rapid shape adaptability for accelerated bacteria-infected wound healing. Bioact. Mater. 2021, 6, 2647-2657. [CrossRef]

33. Guzel Kaya, G.; Yilmaz, E.; Deveci, H. A novel silica xerogel synthesized from volcanic tuff as an adsorbent for high-efficient removal of methylene blue: Parameter optimization using Taguchi experimental design. J. Chem. Technol. Biotechnol. 2019, 94, 2729-2737. [CrossRef]

34. Moriones, P.; Echeverria, J.C.; Parra, J.B.; Garrido, J.J. Phenyl siloxane hybrid xerogels: Structure and porous texture. Adsorption 2019, 26, 177-188. [CrossRef]

35. Zhang, H.; Hu, Q.; Zheng, X.; Yin, Y.; Wu, H.; Jiang, Z. Incorporating phosphoric acid-functionalized polydopamine into Nafion polymer by in situ sol-gel method for enhanced proton conductivity. J. Membr. Sci. 2019, 570, 236-244. [CrossRef]

36. Tian, Y.; Cao, Y.; Wang, Y.; Yang, W.; Feng, J. Realizing ultrahigh modulus and high strength of macroscopic graphene oxide papers through crosslinking of mussel-inspired polymers. Adv. Mater. 2013, 25, 2980-2983. [CrossRef] [PubMed]

37. Ganonyan, N.; Benmelech, N.; Bar, G.; Gvishi, R.; Avnir, D. Entrapment of enzymes in silica aerogels. Mater. Today 2020, 33 , 24-35. [CrossRef]

38. Chao, C.; Liu, J.; Wang, J.; Zhang, Y.; Zhang, B.; Zhang, Y.; Xiang, X.; Chen, R. Surface modification of halloysite nanotubes with dopamine for enzyme immobilization. ACS Appl. Mater. Interfaces 2013, 5, 10559-10564. [CrossRef]

39. Zangmeister, R.A.; Morris, T.A.; Tarlov, M.J. Characterization of polydopamine thin films deposited at short times by autoxidation of dopamine. Langmuir 2013, 29, 8619-8628. [CrossRef]

40. Sing, K.S.W. Reporting physisorption data for gas/solid systems with special reference to the determination of surface area and porosity (Recommendations 1984). Pure Appl. Chem. 1985, 57, 603-619. [CrossRef]

41. Lai, Y.; Xia, W.; Li, J.; Pan, J.; Jiang, C.; Cai, Z.; Wu, C.; Huang, X.; Wang, T.; He, J. A confinement strategy for stabilizing two-dimensional carbon/CoP hybrids with enhanced hydrogen evolution. Electrochim. Acta. 2021, 375, 137966. [CrossRef]

42. Liu, Y.; Zeng, Z.; Zeng, G.; Tang, L.; Pang, Y.; Li, Z.; Liu, C.; Lei, X.; Wu, M.; Ren, P.; et al. Immobilization of laccase on magnetic bimodal mesoporous carbon and the application in the removal of phenolic compounds. Bioresour. Technol. 2011, 102, 3653-3661. [CrossRef]

43. Nadargi, D.; Gurav, J.; Marioni, M.A.; Romer, S.; Matam, S.; Koebel, M.M. Methyltrimethoxysilane (MTMS)-based silica-iron oxide superhydrophobic nanocomposites. J. Colloid Interface Sci. 2015, 459, 123-126. [CrossRef] [PubMed]

44. Owens, G.J.; Singh, R.K.; Foroutan, F.; Alqaysi, M.; Han, C.-M.; Mahapatra, C.; Kim, H.-W.; Knowles, J.C. Sol-gel based materials for biomedical applications. Prog. Mater. Sci. 2016, 77, 1-79. [CrossRef]

45. Chao, C.; Zhang, B.; Zhai, R.; Xiang, X.; Liu, J.; Chen, R. Natural Nanotube-Based Biomimetic Porous Microspheres for Significantly Enhanced Biomolecule Immobilization. ACS Sustain. Chem. Eng. 2013, 2, 396-403. [CrossRef]

46. Ni, K.; Lu, H.; Wang, C.; Black, K.C.; Wei, D.; Ren, Y.; Messersmith, P.B. A novel technique for in situ aggregation of Gluconobacter oxydans using bio-adhesive magnetic nanoparticles. Biotechnol. Bioeng. 2012, 109, 2970-2977. [CrossRef]

47. Niu, Z.; He, X.; Huang, T.; Tang, B.; Cheng, X.; Zhang, Y.; Shao, Z. A facile preparation of transparent methyltriethoxysilane based silica xerogel monoliths at ambient pressure drying. Microporous Mesoporous Mater. 2019, 286, 98-104. [CrossRef]

48. Léonard, A.; Blacher, S.; Crine, M.; Jomaa, W. Evolution of mechanical properties and final textural properties of resorcinolformaldehyde xerogels during ambient air drying. J. Non-Cryst. Solids 2008, 354, 831-838. [CrossRef]

49. Sedo, J.; Saiz-Poseu, J.; Busque, F.; Ruiz-Molina, D. Catechol-based biomimetic functional materials. Adv. Mater. 2013, $25,653-701$. [CrossRef]

50. Zhao, Z.; Liu, J.; Hahn, M.; Qiao, S.; Middelberg, A.P.J.; He, L. Encapsulation of lipase in mesoporous silica yolk-shell spheres with enhanced enzyme stability. RSC Adv. 2013, 3, 22008-22013. [CrossRef] 
51. Mu, Q.; Liu, W.; Xing, Y.; Zhou, H.; Li, Z.; Zhang, Y.; Ji, L.; Wang, F.; Si, Z.; Zhang, B.; et al. Protein Binding by Functionalized Multiwalled Carbon Nanotubes Is Governed by the Surface Chemistry of Both Parties and the Nanotube Diameter. J. Phys. Chem. C 2008, 112, 3300-3307. [CrossRef]

52. Zhang, C.; Luo, S.; Chen, W. Activity of catalase adsorbed to carbon nanotubes: Effects of carbon nanotube surface properties. Talanta 2013, 113, 142-147. [CrossRef]

53. Sathishkumar, P.; Chae, J.C.; Unnithan, A.R.; Palvannan, T.; Kim, H.Y.; Lee, K.J. Laccase-poly(lactic-co-glycolic acid) (PLGA) nanofiber: Highly stable, reusable, and efficacious for the transformation of diclofenac. Enzym. Microb. Technol. 2012, 51, 113-118. [CrossRef]

54. Bao, C.; Xu, X.; Chen, J.; Zhang, Q. Synthesis of biodegradable protein-poly(e-caprolactone) conjugates via enzymatic ring opening polymerization. Polym. Chem. 2020, 11, 682-686. [CrossRef]

55. Huang, S.M.; Huang, H.Y.; Chen, Y.M.; Kuo, C.H.; Shieh, C.J. Continuous Production of 2-Phenylethyl Acetate in a Solvent-Free System Using a Packed-Bed Reactor with Novozym ${ }^{\circledR}$ 435. Catalysts 2020, 10, 714. [CrossRef]

56. Virgen-Ortíz, J.J.; Tacias-Pascacio, V.G.; Hirata, D.B.; Torrestiana-Sanchez, B.; Rosales-Quintero, A.; Fernandez-Lafuente, R. Relevance of substrates and products on the desorption of lipases physically adsorbed on hydrophobic supports. Enzym. Microb. Technol. 2017, 96, 31-35. [CrossRef]

57. Jiang, Y.; Zhai, J.; Zhou, L.; He, Y.; Ma, L.; Gao, J. Enzyme@silica hybrid nanoflowers shielding in polydopamine layer for the improvement of enzyme stability. Biochem. Eng. J. 2018, 132, 196-205. [CrossRef]

58. Pires-Cabral, P.; Da Fonseca, M.; Ferreira-Dias, S. Synthesis of ethyl butyrate in organic media catalyzed by Candida rugosalipase immobilized in polyurethane foams: A kinetic study. Biochem. Eng. J. 2009, 43, 327-332. [CrossRef]

59. Gawas, S.D.; Jadhav, S.V.; Rathod, V.K. Solvent free lipase catalysed synthesis of ethyl laurate: Optimization and kinetic studies. Appl. Biochem. Biotechnol. 2016, 180, 1428-1445. [CrossRef]

60. Wang, H.; Duan, B.; Li, H.; Li, S.; Lu, Y.; Liu, Z.; Su, W. PEGylation and macroporous carrier adsorption enabled long-term enzymatic transesterification. N. J. Chem. 2020, 44, 3463-3470. [CrossRef] 